Jurnal Ekonomi dan Industri

e-ISSN: 2656-3169

Volume 21, No.1, Januari-April 2020

p-ISSN: 0853-5248

\title{
PENGARUH KEPEMIMPINAN DAN MOTIVASI TERHADAP KINERJA KARYAWAN PT. CIPTA NIAGA SEMESTA
}

\author{
Rizki Bayu Permana ${ }^{1)}$ \\ ${ }^{1)}$ Mahasiswa Program Studi Manajemen FE UNKRIS
}

\author{
Ahmad Hermanto ${ }^{2)}$ \\ 2) Dosen Program Studi Manajemen FE UNKRIS \\ Alamat: Kampus UNKRIS, Jatiwaringin Jakarta Timur \\ Email : hermanto.unkris@gmail.com
}

\begin{abstract}
The purpose of this study was to determine the effect of leadership and work motivation on the performance of employees of PT. Cipta Niaga Universe. The research method using descriptive analysis, linear regression analysis both partially and multiple The findings are that Leadership can encourage employee performance improvement, this can be seen from the ability to analyze the leader to supervise the work of subordinates, can provide direction, dare to rebuke subordinates if there are errors in work, the leader is willing to accept opinions and suggestions from subordinates, the leader is firm in his duties and faces subordinates. Work motivation can encourage improvement in employee performance, where a good work environment, salaries received by employees as expected, there are incentives for those who excel, there is work protection and company recognition of employee work performance.
\end{abstract}

Keywords: Leadership, motivation and employee performance

\section{PENDAHULUAN}

Sumber Daya Manusia merupakan salah satu faktor yang selalu terdapat dalam setiap organisasi. Suatu perusahaan agar dapat mencapai produktivitas dan tujuannya jika di dukung oleh sumber daya manusia yang berkualitas. Oleh karena itu sumber daya manusia memegang peranan yang sangat penting dalam suatu perusahaan dalam melakukan kegiatannya, pemimpin harus dapat menggerakan sekelompok karyawan. Berhasil tidaknya suatu perusahaan tergantung kerjasama antara pimpinan dan karyawan. Berbagai bidang khususnya kehidupan berorganisasi, faktor manusia merupakan masalah utama di setiap kegiatan yang ada didalamnya. Organisasi merupakan suatu sistem aktivitas kerjasama yang dilakukan oleh dua orang atau lebih. Semua tindakan yang diambil dalam setiap kegiatan diprakarsai dan ditentukan oleh manusia yang menjadi anggota perusahaan. Perusahaan membutuhkan adanya faktor sumber daya manusia yang potensial baik pemimpin maupun karyawan pada pola tugas dan pengawasan yang merupakan penentu tercapainya tujuan perusahaan.

Sumber daya manusia merupakan tokoh sentral dalam organisasi maupun perusahaan. Agar aktivitas manajemen berjalan dengan baik dan berjalan lancar, perusahaan harus mempunyai karyawan yang memiliki kemampuan yang dapat membuat perusahaan menjadi lebih berkembang sehingga kinerja karyawan meningkat. Kinerja karyawan dinilai dari segi kualitas maupun kuantitas berdasarkan standar kerja yang ditentukan oleh pihak perusahaan. Kinerja yang baik adalah kinerja yang optimal, yaitu kinerja yang sesuai standar organisasi dan mendukung tercapainya tujuan organisai. Organisasi yang baik adalah organisasi yang berusaha untuk meningkatkan kemampuan 
sumber daya manusianya, karena hal tersebut merupakan faktor kunci untuk meningkatkan kinerja karyawan. Maka sumber daya manusia yang dimaksudkan adalah tenaga kerja, karyawan atau karyawan. Fasilitas yang canggih dan lengkap pun belum merupakan jaminan akan keberhasilan suatu organisasi, tanpa diimbangi kualitas dari karyawan yang akan memanfaatkan fasilitas tersebut. coba kita lihat banyak perusahaan-perusahaan asing yang hanya mempekerjakan hanya beberapa orang saja, hasilnya lebih baik dibandingkan dengan perusahaan-perusahaan nasional yang karyawannya lebih banyak dengan fasilitas yang lengkap pula. Hal ini semua membuktikan bahwa sumber daya manusia dalam suatu organisasi atau perusahaan memerlukan karyawan yang dapat menghasilkan kinerja yang optimal. Kinerja menurut Mangkunegara (2013) adalah "hasil kerja secara kualitas dan kuantitas yang dicapai oleh seorang karyawan dalam melaksanakan tugasnya sesuai dengan tanggung jawab yang diberikan kepadanya".

PT. Cipta Niaga Semesta adalah salah satu perusahaan bagian dari Mayora group yang bergerak di bidang distribusi produk makanan dan minuman ringan. Pada PT. Cipta Niaga Semesta bahwa kepemimpinan dan motivasi memiliki peranan yang sangat penting dalam meningkatkan kinerja karyawan. Berdasarkan pengamatan dari penulis sementara terlihat bahwa belum ratanya pembagian kerja sehingga kurang efektif dalam bekerja dan disiplin kerja yang kurang serta sanksi yang kurang tegas oleh perusahaan. Hal ini menyebabkan kurang puasnya karyawan dan pimpinan kurang memberikan arahan bagi karyawannya sehingga mengakibatkan menurunnya kinerja para karyawan dan ini akan berdampal buruk bagi perusahaan. Semua ini dapat diatasi dengan memberikan motivasi kepada karyawan yang kurangnya motivasi dalam bekerja sehingga masalah yang sering terlambat kekantor teratasi dengan adanya dukungan didalam perusahaan.

Kepemimpinan adalah salah satu fungsi Manajemen untuk mempengaruhi, mengarahkan, memotivasi dan mengawasi orang lain agar dapat melakukan tugas-tugas yang telah direncanakan sehingga mencapai sasaran dan tujuan organisasinya. Kemampuan kepemimpinan atau Leadership seorang Manajer akan sangat mempengaruhi kinerja organisasi terutama dalam hal pencapaian tujuan organisasinya. Kepemimpinan merupakan norma perilaku yang digunakan oleh seseorang pada saat menjadi pemimpin dalam suatu usaha yang mempunyai wibawa dan perilaku seperti pemimpin. Kepemimpinan adalah seseorang yang mempergunakan wewenangan dan kepemimpinannya, mengarahkan bawahan untuk mengerjakan sebagian pekerjaannya dalam mencapai tujuan organisasi. Kepemimpinan baik apabila tujuan perusahaan telah berkomunikasi kepada bawahan dan bawahan telah menerimanya apa yang sudah disampaikan. Seorang pemimpin harus menerapkan kepemimpinan untuk mengelola bawahannya, karena seorang pemimpin akan mempengaruhi keberhasilart perusahaan dalam mencapai tujuannya. Pemimpin harus mendengar ide-ide dan saran dari para bawahan sebelum mengambil keputusan. Kepemimpinan yang tepat akan menimbulkan motivasi seseorang untuk berprestasi. Sukses atau tidaknya karyawan dalam prestasi kerja dapat dipengaruhi oleh kepemimpinan. Didalam menjalankan tugasnya sebagai seorang pemimpin di PT. Cipta Niaga Semesta sejauh ini masih kurang dalam berkomunikasi sehingga menimbulkan persepsi yang berbeda antara pimpinan dan karyawan sehingga menjadi tidak sejalan, yang mengakibatkan timbulnya permasalahan dalam pencapaian tujuan.

Kepemimpinan menurut Gareth dan George (20120). Kepemimpinan adalah "proses dimana seorang individu mempunyai pengaruh terhadap orang lain dan mengilhami, memberi semangat, memotivasi dan mengarahkan kegiatan-kegiatan mereka guna membantu tercapai tujuan kelompok atau organisasi".

Selain kepemimpinan faktor lain yang dapat mempengaruhi kinerja karyawan adalah motivasi, sebagai mana kita ketahui bahwa motovasi adalah dorongan, upaya dan 
keinginan yang ada didalam diri manusia dan memberi daya serta mengarahkan perilaku untuk melaksanakan tugas-tugas yang baik dalam lingkup pekerjaannya. Motivasi sebagai proses yang bermula dari kekuatan dalam hal fisiologis dan psikologis atau kebutuhan yang mengakibatkan perilaku atau dorongan yang ditujukan pada sebuah tujuan yang motivasi. Pengaruh motivasi kerja terhadap kinerja menunjukan hasil yang sama bahwa hubungan antara motivasi dengan kinerja karyawan menunjukan hubungan positif dan signifikan. Kemudian timbul pemikiran bagaimana keseluruhan faktor tersebut saling berkelanjutan sehingga dapat mempengaruhi kinerja karyawan. Karyawan diminta untuk menyelesaikan tugas dan tanggung jawab secara efektif dan efisien. Keberhasilan karyawan dapat diukur melalui kepuasan konsumen, sehingga karyawan merasa bangga dengan hasil kerjanya.

Seperti yang disampaikan oleh Uno (2007), Motivasi dapat diartikan "sebagai suatu dorongan internal dan eksternal dalam diri individu yang diindikasikan dengan adanya keinginan, minat, dan hasrat, dorongan juga kebutuhan; cita-cita dan harapan; serta penghargaan dan penghormatan. Motivasi juga terdapat masalah pada PT. Cipta Niaga Semesta yaitu dengan masalah insentif. Contoh permasalahan insentif dapat di lihat dari insentif yang diterima karyawan PT. Cipta Niaga Semesta yang insentif nya sering telat keluar, juga insentif nya tidak sesuai dengan beban tugas pekerjaan karyawan, maka karyawan PT. Cipta Niaga Semesta kekurangan insentif sehingga berdampak terhambatnya pekerjaan dan kurang termotivasi untuk bekerja.

Peningkatan kinerja karyawan akan membawa kemajuan bagi perusahaan untuk dapat bertahan untuk bersaing dalam suatu lingkungan bisnis yang kompetitif. Oleh karena itu upaya-upaya untuk meningkatkan kinerja karyawan merupakan tugas manejemen untuk mencapai tujuan dan kelangsungan hidup perusahaan terganlung pada kualitas kinerja didalam sumbera daya manusia. Kinerja adalah hasil keija secara kualitas dan kuantitas yang dicapai oleh seseorang karyawan dalam melaksanakan tugasnya sesuai dengannya.

Tujuan penelitian ini adalah untuk mengetahui pengaruh kepemimpinan dan motivasi terhadap kinerja karyawan PT. Cipta Niaga Semesta.

\section{LANDASAN TEORI}

\section{Kinerja Karyawan}

Landasan utama dalam menyelenggarakan pengukuran kinerja yang efektif adalah kesadaran bahwa keberhasilannya paling tidak dipengaruhi oleh masalah prosedur dan proses serta jenis, bentuk atau system pencatatan standar yang digunakan. Seringkali perusahaan khususnya manjemen penilai tertentu menitik beratkan pada bagaimana pengukuran yang tepat dan bagaiman sebenarnya pengukuran kinerja dilaksanakan. Kegiatan penilaian kerja merupakan bagian dari sistem manjemen kinerja yang berkembang dalam perjalanan waktu. Sistem-sistem semacam ini dilandasi kepercayaan bahwa kinerja individu bervariasi dalam perjalanan waktu dan bahwa individu bisa berpengaruh terhadap kinerja mereka.

Mangkunegara (2013) mengatakan kinerja adalah "sebagai hasil kerja secara kualitas dan kuantitas yang dapat dicapai oleh seseorang karyawan dalam melaksanakan tugas sesuai dengan tanggung jawab yang diberikan kepadanya". Sedangkan menurut Wirawan (2015) menyebutkan "kinerja sering juga disebut dengan kinetika kerja atau performance" kinerja juga merupakan suatu fungsi dari hasil atau apa yang dicapai seorang karyawan dan kompetensi yang dapat menjelaskan bagaimana karyawan dapat mencapai hasil tersebut.

Kuswadi (2004) menyampaikan ada beberapa faktor yang mempengaruhi kinerja 
karyawan, adalah sebagai berikut: 1). "Kepuasan karyawan; Kepuasan karyawan merupakan salah satu faktor yang sangat penting untuk mendapatkan hasil kerja yang optimal. Kepuasan karyawan mencerminkan perasaan seseorang terhadap pekerjaannya. Ketika seseorang merasakan kepuasan dalam bekerja, tentunya ia akan berupaya semaksimal mungkin dengan segenap kemampuan yang dimilikinya untuk menyelesaikan tugas pekerjaanya. Dengan demikian kinerja dan hasil kerja karyawan akan meningkat secara optimal. 2). Kemampuan karyawan; Kinerja individual karyawan juga dipengaruhi oleh kemampuan yang dimiliki oleh karyawan itu sendiri. Karyawan dengan kemampuan teknis maupun operasional yang tinggi untuk sebuah tugas akan meningkatkan semangat kerjanya. Seorang karyawan merasa termotivasi dan memiliki kinerja yang baik, jika ia memiliki pengetahuan yang memadai terhadap bidang tugas dan tanggung jawabnya. Oleh karena itu, manajemen hedaknya melakukan suatu upaya untuk meningkatkan pengetahuan karyawan baik melalui pendidikan formal, pelatihan, akses informasi maupun pengalaman. 3). Kepemimpinan; Dalam kehidupan organisasi atau perusahaan, kepemimpinan memegang peranan penting dalam usaha mencapai tujuan yang telah ditetapkan. Baik tidaknya suatu kepemimpinan akan menentukan kinerja karyawan. Kepemimpinan yang berkualitas merupakan sumber motivasi, sumber semangat, dan sumber disiplin dalam melaksanakan tugas yang menjadi tanggung jawab mereka. Oleh karena itu, perusahaan yang ingin sukses harus menunjukan kepemimpinan yang baik dan karyawan yang mempunyai semangat kerja yang tinggi untuk mencapai tujuan perusahaan. 4). Motivasi; Keberhasilan pengelolaan perusahaan sangat ditentukan oleh efektivitas kegiatan pendayagunaan sumber daya manusia. Karena itu manajer harus memiliki teknis-teknis untuk memelihara dan mempertahankan kinerja karyawan, salah satunya dengan memberikan motivasi kepada keryawan agar dapat bekerja secara optimal. 5). Lingkungan kerja; Terciptanya lingkungan kerja baik fisik maupun nonfisik yang kondusif merupakan faktor yang memiliki kontribusi besar dalam meningkatkan kepuasan kerja karyawan. Lingkungan kerja yang nyaman bagi karyawannya dapat meningkatkan kinerja. Sebaliknya lingkungan kerja yang tidak memadai akan dapat menurunkan kinerja dan akhirnya menurunkan motivasi kerja karyawan”.

Mangkunegara (2013) mengemukakan bahwa ada beberapa indikator kinerja karywan, yaitu : 1). "Kualitas; Kualitas kerja adalah seberapa baik seorang karyawan mengerjakan apa yang seharusnya dikerjakan. 2). Kuantitas; Kuantitas kerja adalah seberapa lama seorang karyawan bekerja dalam satu harinya. Kuantitas kerja ini dapat dilihat dari kecepatan kerja setiap pegawai itu masing-masing. 3). Pelaksanaan tugas; Pelaksanaan tugas adalah seberapa jauh karyawan mampu melakukan pekerjaannya dengan akurat atau tidak ada kesalahan. 4). Tanggung jawab; Tanggung jawab terhadap pekerjaan adalah kesadaran akan kewajiban karyawan untuk melaksanakan pekerjaan yang diberikan perusahaan".

\section{Kepemimpinan}

Kepemimpinan adalah sebuah kemampuan atau kekuatan dalam diri seseorang untuk mempengaruhi orang lain dalam hal bekerja, dimana tujuannya adalah untuk mencapai target organisasi yang telah ditentukan. Sedangkan pengertian pemimpin adalah seseorang yang diberi kepercayaan sebagai ketua (kepala) dalam sistem di sebuah organisasi/perusahaan. Dalam berbagai aspek, pengertian kepemimpinan dalam organisasi menjadi hal yang krusial. Dua orang konsultan pengembangan diri, Jack Zenger dan Joseph Folkman menerbitkan hasil sebuah penelitian yang mereka hubungkan dengan skill yang wajib dimiliki oleh pemimpin. Skill ini nantinya yang akan membuat para leader sukses dalam semua bidang organisasi, termasuk bisnis. 
Hasibuan (2013), Kepemimpinan adalah "cara seseorang pemimpinan mempengaruhi perilaku bawahan agar mau bekerja sama dan produktif untuk mencapai tujuan organisasi”. Sedangkan menurut Stoner (2006), pengertian kepemimpinan adalah "sebuah proses mengarahkan dan usaha dalam mempengaruhi kegiatan yang berkaitan dengan anggota kelompok atau organisasi”.

Dari pendapat tersebut dapat disimpulkan kepemimpinan merupakan cara seorang pemimpin dalam mempengaruhi bawahan dengan karakteristik tententu sehingga dapat mencapai tujuan yang diinginkan. Faktor keberhasilan seorang pemimpin salah satunya tergantung dengan teknik kepemimpinan yang dilakukan dalam menciptakan situasi sehingga menyebabkan orang yang dipimpinnya timbul kesadarannya untuk melaksanakan apa yang dikehendaki. Dengan kata lain, efektif atau tidaknya seorang pemimpin tergantung dari bagaimana kemampuannya dalam mengelola dan menerapkan pola kepemimpinannya sesuai dengan situasi dan kondisi organisasi tersebut.

Menurut Miljus dalam Ranupondojo dan Husnan (2010) tangggung jawab pimpinan adalah: 1). "Menentukan tujuan pelaksanaan kerja yang realistis. 2). Melengkapi para karyawan dengan sumber dana yang diperlukan untuk menjalankan tugasnya. 3). Mengkomunikasikan pada para karyawan tentang apa yang diharapkan dari mereka. 4). Memberikan susunan hadiah yang sepadan untuk mendukung prestasi. 5). Mendelegasikan wewenang apabila diberikan dan mengundang partisipasi apabila memungkinkan. 6). Menghilangkan hambatan untuk pelaksanaan pekerjaan yang efektif. 7). Menilai pelaksanaan pekerjaan dan mengkomunikasikan hasilnya. 8). Menunjukkan perhatian kepada karyawan".

Gaya kepemimpinan menurut Sutikno (2014) mengatakan gaya kepemimpinan atau perilaku kepemimpinan atau sering disebut tipe kepemimpinan. Tipe kepemimpinan yang luas dikenal dan diakui keberadaanya adalah sebagai berikut : 1). "Tipe Otokratik. Tipe kepemimpinan ini menganggap bahwa kepemimpinan adalah hak pribadinya (pemimpin), sehingga ia tidak perlu berkonsultasi denganorang lain dan tidak boleh ada orang lain yang turut campur. Seorang pemimpin yang tergolong otokratik memiliki serangkaian karateristik yang biasanya dipandang sebagai karakteristik yang negatif. Seorang pemimpin otokratik adalah seorang yang egois. Seorang pemimpin otokratik akan menunjukan sikap yang menonjolakan keakuannya, dan selalu mengabaikan peranan bawahan dalam proses pengambilan keputusan, tidak mau menerima saran dan pandangan bawahannya. 2). Tipe Kendali Bebas atau Masa Bodo (Laisez Faire). Tipe kepemimpinan ini merupakan kebalikan dari tipe kepemimpinan otokratik. Dalam kepemimpinan tipe ini sang pemimpin biasanya menunjukkan perilaku yang pasif dan seringkali menghindar diri dari tanggung jawab. Seorang pemimpin yang kendali bebas cenderung memilih peran yang pasif dan membiarkan organisasi berjalan menurut temponya sendiri. Disini seorang pemimpin mempunyai keyakinan bebas dengan memberikan kebebasan yang seluasluasnya terhadap bawahan maka semua usahanya akan cepat berhasil. 3). Tipe Paternalistik. Persepsi seorang pemimpin yang paternalistik tentang peranannya dalam kehidupan organisasi dapat dikatakan diwarnai oleh harapan bawahan kepadanya. Harapan bawahan berwujud keinginan agar pemimpin mampu berperan sebagai bapak yang bersifat melindungi dan layak dijadikan sebagai tempat bertanya dan untuk memperoleh petunjuk, memberikan perhatian terhadap kepentingan dan kesejahteraan bawahannya. Pemimpin yang paternalistik mengharapkan agar legitimasi kepemimpinannya merupakan penerimaan atas peranannya yang dominan dalam kehidupan organisasi. 4). Tipe Kharismatik. Seorang pemimpin yang kharismatik memiliki karakteristik khusus yaitu daya tariknya yang sangat memikat, sehingga mampu memperoleh pengikut yang sangat besar dan para pengikutnya tidak selalu dapat menjelaskan secara konkrit mengapa orang 
tersebut itu dikagumi. Hingga sekarang, para ahli belum berhasil menemukan sebab-sebab mengapa seorang pemimpin memiliki kharisma. Yang diketahui ialah bahwa pemimpin yang demikian mempunyai daya penarik yang amat besar. 5). Tipe Militeristik. Pemimpin tipe militeristik berbeda dengan seorang pemimpin organisasi militer. Pemimpin yang bertipe militeristik ialah pemimpin dalam menggerakan bawahannya lebih sering mempergunakan sistem perintah, senang bergantung kepada pangkat dan jabatannya, dan senang kepada formalitas yang berlebih-lebihan. Menuntut disiplin yang tinggi dan kaku dari bawahannya, dan sukar menerima kritikan dari bawahannya. 6). Tipe Pseudodemokratik. Tipe ini disebut juga kepemimpinan manipulatif atau semi demokratik. Tipe kepemimpinan ini ditandai oleh adanya sikap seorang pemimpin yang berusaha mengemukakan keinginan-keinginannya dan setelah itu membuat sebuah panitia, dengan berpura-pura untuk berunding tetapi yang sebenarnya tiada lain untuk mengesahkan saransarannya. Pemimpin seperti ini menjadikan demokrasi sebagai selubung untuk memperoleh kemenangan tertentu. Pemimpin yang bertipe pseudo-demokratik hanya tampaknya saja bersikap demokratis padahal sebenarnya dia bersikap otokratis. Pemimpin ini menganut demokrasi semu dan lebih mengarah kepada kegiatan pemimpin yang otoriter dalam bentuk yang halus, samarsamar. 7). Tipe Demokratik. Tipe demokratik adalah tipe pemimpin yang demokratis, dan bukan kerena dipilihnya sipemipin secara demokratis. Tipe kepemimpinan dimana pemimpin selalu bersedia menerima dan menghargai saransaran, pendapat, dan nasehat dari staf dan bawahan, melalui forum musyawarah untuk mencapai kata sepakat. Kepemimpinan demokratik adalah kepemimpinan yang aktif, dinamis, dan terarah. Kegiatan-kegiatan pengendalian dilaksanakan secara tertib dan bertanggung jawab. Pembagian tugas disertai pelimpahan wewenang dan tanggung jawab yang jelas, memungkinkan setiap anggota berpartisipasi secara aktif".

Indikator kepemimpinan menurut Martoyo (2011) diantaranya: 1). "Kemampuan analitis; Kemampuan menganalisa situasi yang dihadapi secara teliti, matang, dan mantap, merupakan prasyarat untuk suksesnya kepemimpinan seseorang. 2). Ketrampilan berkomunikasi; Dalam memberikan perintah, petunjuk, pedoman, nasihat, seorang pemimpin harus menguasai teknik-teknik berkomunikasi. 3). Keberanian; Semakin tinggi kedudukan seseorang dalam organisasi ia perlu memiliki keberanian yang semakin besar dalam melaksanakan tugas pokoknya yang telah dipercayakan padanya. 4). Kemampuan Mendengar; Salah satu sifat yang perlu dimiliki oleh setiap pemimpin adalah kemampuannya serta kemauannya mendengar pendapat dan atau saran-saran orang lain, terutama bawahan-bawahannya. 5). Ketegasan; Ketegasan dalam menghadapi bawahan dan menghadapi ketidaktentutan, sangat penting bagi seorang pemimpin”.

\section{Motivasi}

Pengertian Motivasi merupakan suatu perubahan yang terjadi pada diri seseorang yang muncul adanya gejala perasaan, kejiwaan dan emosi sehingga mendorong individu untuk melakukan atau bertindak sesuatu yang disebabkan karena kebutuhan, keinginan dan tujuan.

Pengertian dan definisi motivasi menurut pendapat para ahli: Menurut Flippo (2002) dalam Hasibuan (2013), motivasi adalah "suatu keahlian dalam mengarahkan pegawai dan organisasi agar mau bekerja secara berhasil, sehingga keinginan para pegawai dan tujuan organisasi sekaligus tercapai". Uno (2007), motivasi dapat diartikan "sebagai dorongan internal dan eksternal dalam diri seseorang yang diindikasikan dengan adanya; hasrat dan minat; dorongan dan kebutuhan; harapan dan cita-cita; penghargaan dan penghormatan". Kemudian menurut Siagian (2009), menyatakan bahwa "motivasi merupakan daya dorong bagi seseorang untuk memberikan kontribusi yang sebesar mungkin demi keberhasilan 
organisasi mencapai tujuannya”.

Dari pengertian maupun definisi motivasi para ahli diatas maka dapat disimpulkan bahwa motivasi merupakan suatu keadaan atau kondisi yang mendorong, merangsang atau menggerakan seseorang untuk melakukan sesuatu atau kegiatan yang dilakukannya sehingga ia dapat mencapai tujuannya.

Hasibuan (2013) ada beberapa tujuan pemberian motivasi, yaitu sebagai berikut: 1). "Mendorong gairah dan semangat kerja karyawan. 2). Meningkatkan moral dan kepuasan kerja karyawan. 3). Meningkatkan produktivitas kerja karyawan. 4). Mempertahankan loyalitas dan kestabilan. 5). Meningkatkan kedisiplinan dan menurunkan tingkat absensi karyawan. 6). Mengefektifkan pengadaan karyawan. 7). Menciptakan suasana dan hubungan kerja yang baik. 8). Meningkatkan kreatifitas dan partisipasi karyawan. 9). Meningkatkan tingkat kesejahteraan karyawan. 10). Mempertinggi rasa tanggung jawab karyawan terhadap tugas-tugasnya. 11). Meningkatkan efisiensi penggunaan alat-alat dan bahan baku".

Motivasi diperlukan dalam suatu organisasi karena dapat mendorong kinerja karyawan. Tujuan ini dapat dicapai jika manajer suatu organisasi memahami dengan tepat jenis-jenis motivasi dalam rangka mendorong karyawan untuk bekerja dan memberikan insentif terhadap hasil pekerjaannya. Disisi lain karyawan dapat menghindarkan diri untuk berperilaku pada jenis motivasi negatif yang menyebabkan terhambatnya tujuan organisasi.

Sebenarnya banyak pembahasan teori-teori motivasi, namun yang akan menonjol ialah pendapat-pendapat dari: 1). Teori A. H. Maslow. Menamakan teorinya Maslow's Need Hierarchy Theory atau A Theoy of Human Motivation diilhami Human Science Theory ari Elton Mayo. Hierarki kebutuhan mengikuti teori jamak yakni seseorang berperilaku atau bekerja karena adanya dorongan untuk memenuhi bermacam-macam kebutuhan. Maslow bependapat bahwa kebutuhan yang diinginkan seseorang itu berjenjeng. Artinya, jika kebutuhan yang pertama telah terpenuhi, maka kebutuhan tingkat kedua akan muncul menjadi yang utama. Selanjutnya jika kebutuhan tingkat kedua telah terpenuhi, muncul kebutuhan tingkat ketiga dan seterusnya samapai tingkat kebutuhan kelima. 2). Teori Douglas McGregor. Douglas McGregor adalah seorang psikolog Amerika yang memimpin suatu varietas proyek riset dalam hal motivasi dan tingkah laku umum dari para anggota organisasi. Ia juga merupakan seorang guru besar manajemen pada lembaga teknik Massachusetts (Massachusetts Institute of Technology). McGregor terkenal teori X dan Y-nya dalam bukunya The Human Side of Enterprise (Segi Manusiawi Perusahaan). Teori ini didasarkan pada asumsi bahwa manusia secara jelas dan tegas dapat dibedakan atas manusia penganut teori $\mathrm{X}$ (Teori Tradisional) dan manusia penganut teori $\mathrm{Y}$ (Teori Demokratis). 3). Teori Frederrick Herzberg. Frederrick Herzberg mengemukaan suatu teori yang berhubungan langsung dengan kepuasan kerja yang didasarkan pada penelitian bersama di kota Pitsburg dan sekitarnya. Dari hasil penelitian ini dikembangkan suatu gagasan bahwa ada 2 rangkaian kondisi yang mempengaruhi seseorang di dalam pekerjaanya: a). Rangkaian kondisi pertama disebut "faktor motivator". b). Rangkaian kondisi kedua disebut "faktor hygiene". 4). Teori David McClelland. David McClelland adalah Direktur Pusat Penelitian Kepribadian di Universitas Harvard. Beliau bersama kawan-kawannya mempelajari persoalan yang berkaitan dengan keberhasilan seseorang (the needs of achive). Hasilnya adalah suatu konsep yang berhubungan dengan upaya bagaimana dapat mencapai keberhasilan. Karena itu teorinya disebut "Achievement Motivation Theory". Teori ini berpendapat bahwa karyawan mempunyai cadangan energi potensial bagaimana energi dilepaskan dan digunakan tergantung kepada kekuatan dorongan motivasi seseorang dan situasi serta peluang yang tersedia. Hal-hal yang memotivasi orang tersebut antara lain: a). Kebutuhan akan prestasi. b). Kebutuhan akan 
afiliasi. c). Kebutuhan akan kekuasaan.

Rivai (2006), ada beberapa indikator yang mempengaruhi motivasi: 1). "Lingkungan kerja; Lingkungan kerja yaitu segala sesuatu kondisi yang ada dan dirasakan para karyawan yang bisa berpengaruh pada diri karyawan dalam melaksakan tugas-tugas para karyawan. 2). Gaji yang adil dan kompetitif; Gaji yang adil dan kompetitif yaitu balas jasa dalam bentuk uang yang diterima karyawan sebagai konsekuensi dan statusnya sebagai karyawan yang memberikan kontribusi dalam pencapaian tujuan perusahan. 3). Insentif; Insentif yaitu pendorong atau perangsang yang diberikan dengan sengaja kepada karyawan agar semangat lebih besar untuk berprestasi. 4). Rasa aman dalam bekerja; Dalam hal ini rasa aman dalam bekerja merupakan hal yang membuat karyawan merasa dipelihara perusahaan, misalnya perusahaan memberikan asuransi kesehatan kepada karyawannya. 5). Penghargaan atau prestasi; Karyawan akan merasa lebih senang bila hasil kerja yang dicapai lebih baik dibandingkan dengan karyawan lainnya serta bangga bila pimpinan memberikan penghargaan kepada karywan yang berprestasi”.

\section{METODE PENELITIAN}

Penelitian ini untuk menjelaskan hubungan kausalitas variabel kepemimpinan dan motivasi. Data yang digunakan dalam penelitian ini merupakan data primer melalui pengisian kuesioner kepada para karyawan. Metode analisis yang digunakan adalah metode analisis regresi linear sederhana dan berganda. Populasi dalam penelitian ini adalah karyawan PT. Citra Niaga Semesta berjumlah 90 orang.

Teknik pengambilan sampel dalam penelitian ini menggunakan teknik sampling jenuh (sensus), yaitu teknik pengumpulan sampel bila semua anggota populasi digunakan sebagai sampel. Merujuk atas pernyataan tersebut maka jumlah sampel yang digunakan adalah seluruh karyawan yang berjumlah 90 orang

\section{HASIL PENELITIAN DAN PEMBAHASAN}

\section{Uji Instrumen Data}

Berdasarkan uraian tersebut di atas, maka untuk dapat menentukan apakah variabel kepemimpinan dan motivasi dapat dijadikan pengukur terhadap kinerja karyawan PT. Citra Niaga Semesta. Namun sebelumnya data diolah terlebih dahulu dan dilakukan pengujian terhadap varibel yang digunakan yaitu kepemimpinan dan motivasi untuk mengetahui apakah data tersebut akurat dan dapat dipercaya.

\section{Uji Validitas}

Pengujian validitas ini dilakukan untuk menguji apakah tiap butir pernyataan telah mewakili indikator yang akan diteliti, persyaratan minimum untuk dapat dikatakan valid adalah $\mathrm{r}=0,30$. Jadi, apabila korelasi antara butir-butir item pernyataan dengan skor total kurang dari 0,30, maka butiran dalam instrumen tersebut dapat dikatakan tidak valid. Uji validitas dilakukan dengan melihat korelasi antara skor masing-masing item pernyataan dengan skor total.

\section{Uji Validitas Instrumen Variabel}

Dari perhitungan koefisien korelasi skor tiap butir pernyataan dari 90 responden tentang instrument kepemimpinan dengan jumlah 10 pernyataan; instrumen motivasi 10 pernyataan dan instrumen kinerja karyawan 8 pernyataan dengan total skor setiap 
responden diperoleh hasil yang disajikan dalam tabel sebagai berikut:

Tabel 1: Hasil Uji Validitas Instrumen Variabel

\begin{tabular}{|c|c|c|c|c|c|}
\hline \multirow[b]{2}{*}{ Pernyataan } & \multicolumn{3}{|c|}{ R Hitung } & \multirow[b]{2}{*}{ R Kritis } & \multirow[b]{2}{*}{ Kesimpulan } \\
\hline & Kepemimpinan & Motivasi & $\begin{array}{c}\text { Kinerja } \\
\text { Karyawan }\end{array}$ & & \\
\hline Inst. 1 & 0.532 & 0.505 & 0.534 & 0.300 & Valid \\
\hline Inst. 2 & 0.542 & 0.655 & 0.553 & 0.300 & Valid \\
\hline Inst. 3 & 0.566 & 0.511 & 0.634 & 0.300 & Valid \\
\hline Inst. 4 & 0.534 & 0.442 & 0.491 & 0.300 & Valid \\
\hline Inst. 5 & 0.345 & 0.468 & 0.593 & 0.300 & Valid \\
\hline Inst. 6 & 0.491 & 0.480 & 0.610 & 0.300 & Valid \\
\hline Inst. 7 & 0.429 & 0.519 & 0.461 & 0.300 & Valid \\
\hline Inst. 8 & 0.600 & 0.551 & 0.458 & 0.300 & Valid \\
\hline Inst. 9 & 0.513 & 0.524 & - & 0.300 & Valid \\
\hline Inst. 10 & 0.481 & 0.473 & - & 0.300 & Valid \\
\hline
\end{tabular}

Sumber: Data primer, 2019

Berdasarkan Tabel 1, dapat disimpulkan bahwa dari semua butir pernyataan variabel kepemimpinan, motivasi dan kinerja karyawan hasilnya adalah valid.

\section{Uji Reliabilitas}

Pengujian reliabilitas ini dilakukan untuk menguji seberapa jauh hasil pengukuran yang dapat diandalkan secara konsisten. Pada tabel hasil pengujian reliabilitas berikut, diketahui bahwa semua variabel mempunyai alpha di atas 0,6 yang berarti bahwa semua variabel dalam penelitian ini dapat diandalkan.

Tabel 2: Hasil Uji Reliabilitas Variabel

\begin{tabular}{lcc}
\hline \multicolumn{1}{c}{ Variabel } & Cronbach's Alpha & Keterangan \\
\hline Kepemimpinan & 0.671 & Reliabel \\
Motivasi & 0.686 & Reliabel \\
Kinerja Karyawan & 0.646 & Reliabel \\
\hline \multicolumn{2}{l}{ Sumber: Hasil pengolahan data, 2019}
\end{tabular}

Berdasarkan Tabel 2, dapat disimpulkan bahwa nilai Cronbach's Alpha positif dimana lebih besar dari 0,6 yang merupakan batas minimal koefisien reliabilitas dapat dianggap baik. Dengan demikian, dikatakan bahwa pernyataan di atas reliabel.

\section{Analisis Hasil Penelitian}

Tabel 3: Pengaruh Kepemimpinan dan Motivasi Terhadap Kinerja Karyawan PT. Cipta Niaga Semesta

\begin{tabular}{|c|c|c|c|c|c|c|}
\hline \multirow[b]{2}{*}{ Variabel } & \multicolumn{6}{|c|}{ Parameter } \\
\hline & Mult. R & R Square & Konstanta & $\begin{array}{c}\text { Koef. } \\
\text { Regresi }\end{array}$ & Sig. & $\alpha$ \\
\hline $\begin{array}{l}\text { Kepemimpinan } \\
\text { Motivasi }\end{array}$ & 0.850 & 0.722 & 4.199 & $\begin{array}{l}0.398 \\
0.341\end{array}$ & 0.000 & 0.05 \\
\hline
\end{tabular}

\section{Pengujian Signifikansi}




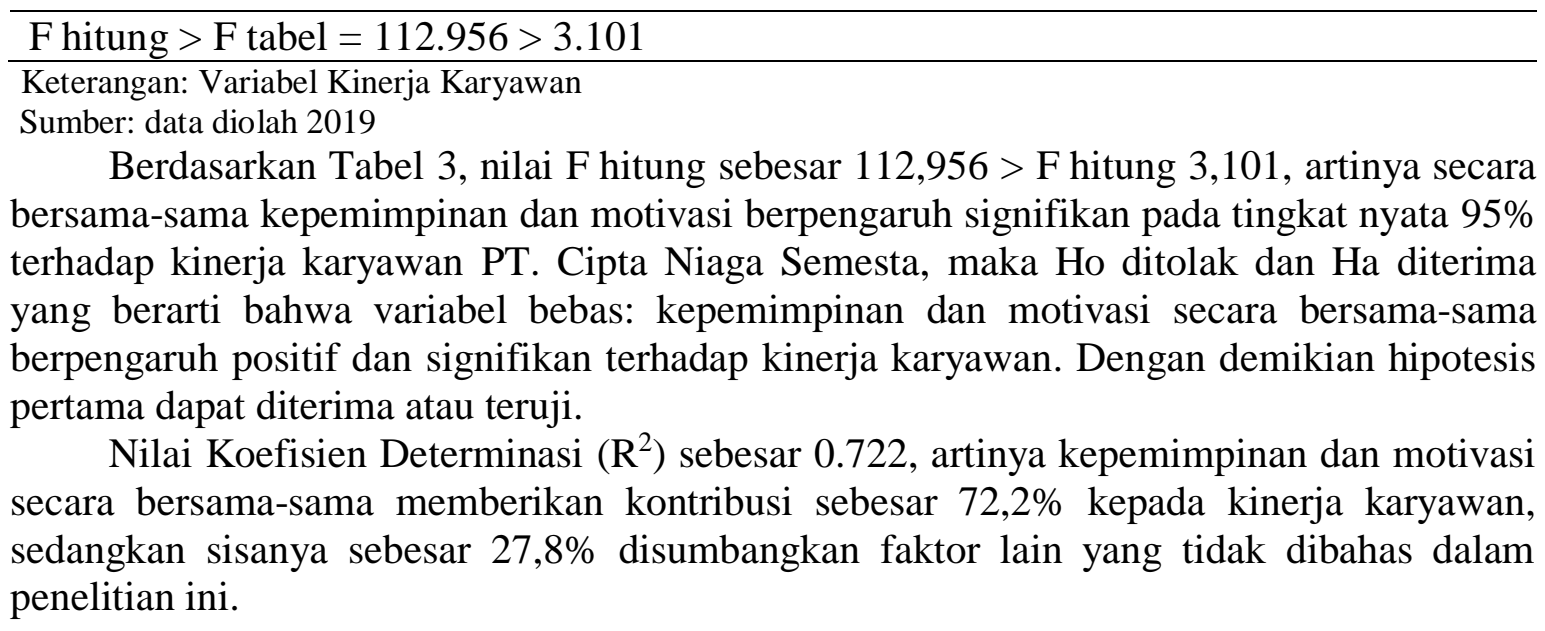

$$
\text { Persamaan Regresi } Y=4,199+0,398\left(X_{1}\right)+0,341\left(X_{2}\right)
$$

Kepemimpinan dan motivasi berpengaruh positif dan signifikan terhadap kinerja karyawan PT. Cipta Niaga Semesta, pada tingkat nyata 95\%. Koefisien kepemimpinan sebesar 0,398, artinya jika ada peningkatan kepemimpinan, maka kinerja karyawan PT. Cipta Niaga Semesta akan meningkat atau sebaliknya dengan asumsi motivasi tidak berubah. Koefisien motivasi sebesar 0,341, artinya jika ada peningkatan motivasi, maka kinerja karyawan PT. Cipta Niaga Semesta, akan meningkat atau sebaliknya, dengan asumsi kepemimpinan tidak berubah.

Tabel 4: Pengaruh Kepemimpinan Terhadap Kinerja Karyawan PT. Cipta Niaga Semesta

\begin{tabular}{|c|c|c|c|c|c|c|}
\hline \multirow[b]{2}{*}{ Variabel } & \multicolumn{6}{|c|}{ Parameter } \\
\hline & $\mathbf{R}$ & R Square & Konstanta & $\begin{array}{c}\text { Koef. } \\
\text { Regresi }\end{array}$ & Sig. & $\boldsymbol{\alpha}$ \\
\hline Kepemimpinan & 0.802 & 0.643 & 8.192 & 0.641 & 0.000 & 0.05 \\
\hline \multicolumn{7}{|c|}{ Pengujian Signifikansi } \\
\hline $\mathrm{t}$ hitung $>\mathrm{t}$ tabe & 12.58 & 987 & & & & \\
\hline
\end{tabular}

Keterangan: Variabel Kinerja Karyawan

Sumber: data diolah 2019

Berdasarkan Tabel 4, nilai koefisien determinasi $\left(\mathrm{R}^{2}\right)$ sebesar 0.643 , artinya kepemimpinan memberikan kontribusi sebesar 64,2\% terhadap kinerja karyawan PT. Cipta Niaga Semesta, sedangkan sisanya sebesar $35,8 \%$ disumbangkan faktor lain yang tidak diteliti, seperti motivasi.

$$
\text { Persamaan Regresi Y = 8,192+0,641 }\left(\mathrm{X}_{1}\right)
$$

Kepemimpinan berpengaruh signifikan pada tingkat nyata $95 \%$ terhadap kinerja karyawan PT. Cipta Niaga Semesta. Koefisien kepemimpinan sebesar 0,641, artinya jika ada peningkatan kepemimpinan, maka kinerja karyawan PT. Cipta Niaga Semesta akan meningkat atau sebaliknya. Untuk menguji hubungan parsial variabel kepemimpinan terhadap kinerja karyawan signifikan atau tidak, dilakukan pengujian $\mathrm{t}$ hitung dibandingkan dengan $\mathrm{t}$ tabel dengan tingkat kepercayaan $(\alpha)=0.05$, hasilnya adalah $\mathrm{t}$ tabel $=1,987$ yang dilihat dari tabel distribusi $\mathrm{t}$ (derajat kebebasan $=\mathrm{n}-2 ;(90-2=88)$, dengan uji dua 
pihak). Berdasarkan perhitungan tersebut di atas dapat dinyatakan bahwa nilai $\quad \mathrm{t}_{\text {hitung }}=$ 12,589 dibandingkan dengan $t$ tabel 1,987 atau $t$ hitung $>t_{\text {tabel }}(12,589>1,987)$, maka Ho ditolak dan Ha diterima, dapat diartikan terdapat pengaruh yang signifikan kepemimpinan terhadap kinerja karyawan PT. Cipta Niaga Semesta. Dengan demikian hipotesis kedua dapat diterima atau teruji.

Tabel 5: Pengaruh Motivasi Terhadap Kinerja Karyawan PT. Cipta Niaga Semesta

\begin{tabular}{lcccccc}
\hline \multirow{2}{*}{ Variabel } & $\mathbf{R}$ & R Square & Konstanta & $\begin{array}{c}\text { Koef. } \\
\text { Regresi }\end{array}$ & Sig. & $\boldsymbol{\alpha}$ \\
\cline { 2 - 7 } & 0.758 & 0.575 & 5.898 & 0.960 & 0.000 & 0.5 \\
\hline Motivasi & 0.590 & & & \\
\hline Pengujian Signifikansi & & & & \\
\hline t hitung $>$ t tabel $=11.673>1.987$ &
\end{tabular}

Keterangan: Variabel Kinerja Karyawan

Sumber: data diolah 2019

Berdasarkan Tabel 5, nilai koefisien determinasi $\left(\mathrm{R}^{2}\right)$ sebesar 0.575 , artinya motivasi memberikan kontribusi sebesar 57,5\% terhadap kinerja karyawan PT. Cipta Niaga Semesta, sedangkan sisanya sebesar $42,5 \%$ disumbangkan faktor lain yang tidak diteliti, seperti kepemimpinan.

$$
\text { Persamaan Regresi } \mathrm{Y}=5,898+0,960\left(\mathrm{X}_{2}\right)
$$

Motivasi berpengaruh signifikan pada tingkat nyata 95\% terhadap kinerja karyawan PT. Cipta Niaga Semesta. Koefisien motivasi sebesar 0,960, artinya jika ada peningkatan motivasi satu kali, maka kinerja karyawan PT. Cipta Niaga Semesta akan meningkat sebesar 0,960 kali atau sebaliknya. Untuk menguji hubungan parsial variabel motivasi terhadap kinerja karyawan signifikan atau tidak, dilakukan pengujian $\mathrm{t}$ hitung dibandingkan dengan $\mathrm{t}$ tabel dengan tingkat kepercayaan $(\alpha)=0.05$, hasilnya adalah $\mathrm{t}$ tabel $=1,987$ yang dilihat dari tabel distribusi $\mathrm{t}$ (derajat kebebasan $=\mathrm{n}-2 ;(90-2=88)$, dengan uji dua pihak). Berdasarkan perhitungan tersebut di atas dapat dinyatakan bahwa nilai $\mathrm{t}$ hitung $=$ 11,673 dibandingkan dengan $t$ tabel 1,987 atau $t$ hitung $>t_{\text {tabel }}(11,673>1,987)$, maka Ho ditolak dan Ha diterima, dapat diartikan terdapat pengaruh yang signifikan motivasi terhadap kinerja karyawan PT. Cipta Niaga Semesta. Dengan demikian hipotesis ketiga dapat diterima atau teruji.

\section{Pembahasan}

\section{Pengaruh Kepemimpinan dan Motivasi Terhadap Kinerja Karyawan}

Berdasarkan hasil analisis diketahui bahwa kepemimpinan dan motivasi dapat mendorong peningkatan kinerja karyawan PT. Cipta Niaga Semesta. Hasil penelitian ini sama dengan hasil penelitian yang dilakukan oleh Inaray, et al, (2016) dan Cahyano, et al, (2016), yaitu menganalisis pengaruh kepemimpinan dan motivasi terhadap kenerja karyawan.

\section{Pengaruh Kepemimpinan Terhadap Kinerja Karyawan}


Hasil penelitian ini menunjukkan bahwa kepemimpinan mendorong peningkatan kinerja karyawan. Hal ini dikarenakan bahwa kemampuan analisis pemimpinan teliti dalam mengawasi pekerjaan bawahan, ketrampilan berkomunikasi pemimpin menguasai tekniknya, keberanian pemimpin menghadapi ketidakpatian, berani menegor bawahan yang membuat kesalahan, mau mendengar pendapat orang lain, menerima saran dari bawahan, pemimpin tegas dalam bertugas, dan tegas menghadapi bawahan. Hasil penelitian ini sesuai dengan penelitian yang dilakukan oleh Rego, et al (2017), yaitu menganalisis pengaruh kepemimpinan terhadap kinerja karyawan.

\section{Pengaruh Motivasi Terhadap Kinerja Karyawan}

Hasil penelitian ini menunjukkan bahwa motivasi dapat mendorong peningkatan kinerja karyawan. Hal ini dikarenakan bahwa lingkungan kerja yang menyengkan, nyaman, hubungan dengan rekan kerja harmonis, gaji yang diterima sesuai dengan peraturan dan dapat memenuhi kebutuhan keluarga, karyawan yang berprestasi mendapat insentif, perusahaan memberikan perlindungan dalam bekerja, adanya dana pensiun bagi karyawan, pengakuan perusahaan atas prestasi kerja karyawan, dan karyawan ingin dihargai oleh pimpinan atas prestasi kerjanya. Hasil penelitian ini sejalan dengan penelitian yang dilakukan oleh Bahrun dan Sinaga, (2015), yaitu menganalisis pengaruh motivasi terhadap kinerja karyawan.

\section{KESIMPULAN DAN SARAN}

\section{Kesimpulan}

Dari hasil analisis dan pembahasan, maka dapat diambil kesimpulan bahwa: 1). Kepemimpinan dan Motivasi kerja berpengaruh positif dan signifikan terhadap kinerja karyawan PT. Cipta Niaga Semesta. 2). Kepemimpinan berpengaruh positif dan signifikan terhadap kinerja karyawan PT. Cipta Niaga Semesta. 3). Motivasi kerja berpengaruh positif dan signifikan terhadap kinerja karyawan PT. Cipta Niaga Semesta.

\section{Saran}

Berdasarkan analisis dan pembahasan pengujian secara empiris suatu kesimpulan yang dikemukakan di atas, Peneliti pada sub bagian ini mencoba memberikan rekomendasi atau saran yang mungkin dapat ditindaklanjuti oleh PT. Cipta Niaga Semesta sebagai berikut : 1). PT. Cipta Niaga Semesta, pemimpin sebaiknya terus memberikan perhatian pada bawahannya, baik dari segi pekerjaan, memberikan motivasi dan juga menjadi panutan bagi bawahan agar para bawahan mau mengikuti semua aturan yang ada di dalam perusahaan. 2). Perusahaan harus terus memantau pekerjaan para pegawai manakala ada yang menurun kinerjanya perlu diberikan motivasi lagi agar karyawan bertambah semangat dalam bekerja, salah satu bentuk motivasi adalah memberikan pengarahan dari pimpinan, dan berikan kesejahteraan yang lebih baik lagi. 3). Bagi peneliti selanjutnya disarankan untuk menambah variabel-variabel lain yang lebih beragam dalam membahas yang berhubungan dengan kinerja karyawan yang bergerak dalam bidang distribusi.

\section{DAFTAR PUSTAKA}

Bahrum, Syazhashah Putra dan Sinaga, Inggrid Wahyuni. 2015. "Pengaruh Kepemimpinan dan Motivasi Kerja Terhadap Kinerja Pegawai”. (Studi Pada Pegawai Lembaga Dewan Kawasan Perdagangan Bebas Pelabuhan Bebas Batam Bintan Karimun). 
Jurnal Akuntansi, Ekonomi dan manajemen Bisnis, Vol. 3, No. 2, 2015, 135-141, ISSN : 2337-7887 (print version).

Cahyono, Wandra Agus,. Hamid, Djamhur, dan Nurtjahjono, Gunawan Eko. 2016. "Pengaruh Kepemimpinan dan Motivasi Kerja Terhadap Kinerja Karyawan". (Studi pada PT. Victory International Futures Malang). dalam Jurnal Administrasi Bisnis (JAB) Vol. 33 No. 2 April 2017. Hal: 1-10.

Flippo, Edwin B. 2002. Manajemen Personalia. Edisi VII Jilid II, TerjemahanAlponso S. Jakaraata : Erlangga.

George, Jennifer and Gareth R Jones. 2012. Understanding and Managing Organizational Behavior. Pearson Education, Inc, New Jersey

Hasibuan, Malayu S. P. 2013. Manajemen Sumber Daya Manusia. Jakarta: PT. Bumi Aksara.

Inary, Jelita Caroline,. Nelwan, Olivia S. dan Lengkong, Victor P.K. 2016 "Pengaruh Kepemimpinan dan Motivasi Kerja Terhadap Kinerja Karyawan Pada PT. Amanah Finance di Manado". Jurnal Berkala Ilmiah Efisiensi, Volume 16 No. 02. Tahun 2016.

Kuswadi, 2004. Cara Mengukur Kepuasan Karyawan. Jakarta: PT. Elex Media Komputindo.

Mangkunegara, Anwar Prabu. 2013. Manajemen Sumber Daya Manusia Perusahaan. Bandung : Remaja Rosda Karya.

Martoyo. Susilo. 2011. Manajemen Sumber Daya Manusia. Yogyakarta : BPFE.

Maslow. Abraham H. 2003. Motivasi dan Kepribadian. Jakarta : Penerbit Surya Grafindo.

Ranupandojo, Heidjrachman dan Husnan, Suad. 2010. Manajemen Personalia. Yogyakarta : BPFE.

Rego, Elvino Bonaparte do,. Supartha Wayan Gede dan Yasa, Ni Nyoman Kerti. 2017. "Pengaruh Kepemimpinan Terhadap Motivasi dan Kinerja Karyawan pada Direktorat Jendral Administrasi dan Keuangan, Kementerian Estatal Timor Leste". E-Jurnal Ekonomi dan Bisnis Universitas Udayana 6.11 (2017): 3731-3764, ISSN : 2337-3067.

Rivai, Veithzal. 2006. Manajemen Sumber Daya Manusia untuk Perusahaan : dari Teori Ke Praktik. Edisi Pertama. Jakaarta : PT. Raja Grafindo Persada.

Siagian, Sondang P. 2009. Kepemimpinan Organisasi dan Perilaku Administrasi. Jakarta : Gunung Agung.

Stoner, James A.F. 2006. Management. Englewood Cliffs, N.J. : Prentice Hall, Inc.

Sugiyono. 2016. Statikstika Untuk Penelitian. Bandung : Penerbit Alfabeta.

Sutikno, Sobry M. 2014. Pemimpin dan Gaya Kepemimpinan. Edisi Pertama. Lombok: Holistica.

Uno, Hamzah B. 2007. Model Pembelajaran Menciptakan Proses Belajar Mengajar yang Kreatif dan Efektif. Jakarta : Bumi Aksara.

Werther, William B. dan Keith Davis. 1996. Manajemen Personalia dan Sumber Daya Manusia. Jakarta: Erlangga.

Wirawan. 2015. Manajemen Sumber Daya Manusia Indonesia. Jakarta: PT Raja Grafindo Persada. 